\title{
FCCBS ISSUE AND WEALTH EFFECTS -A PRE- CRISIS PERIOD PERSPECTIVE: EVIDENCE FROM INDIAN CORPORATE SECTOR
}

\author{
Sayyad Ameen Ahammad \\ Research Scholar, Department of Business Administration, Mangalore University \\ Mangalagangothri, India. \\ Dr. T. Mallikarjunappa \\ Professor, Department of Business Administration, Mangalore University \\ Mangalagangothri, India.
}

\begin{abstract}
FCCBs is a fund raising instrument of Indian corporate sector to access the international investors. The various factors associated with FCCBs send positive and negative signal to the market during its issue, which in turn effect on the shareholders wealth. Majority of Indian FCCBs are issued during 2004-2010 in this period the major crisis period of the Indian stock market also falls.In order to avoid overlap possibilities of crisis effect, this study considered only the FCCBs which was issued during 2004 to 2007. We have used event study methodology for the analysis of 151 FCCB issue effects on shareholders wealth and the results shows the negative effect from FCFCCBs issue on shareholders wealth during the pre-crisis period in India
\end{abstract}

Keywords: FCCBs, Wealth, Pre-crisis, Shareholders, Event study

Cite this Article: Sayyad Ameen Ahammad and Dr. T. Mallikarjunappa, FCCBS Issue and Wealth Effects -A Pre-Crisis Period Perspective: Evidence from Indian Corporate Sector. Journal of Management, 6(6), 2019, pp. 23-28.

http://www.iaeme.com/jom/issues.asp?JType=JOM\&VType=6\&IType=6

\section{INTRODUCTION}

Foreign Currency Convertible Bond (FCCB) is one among the fund raising instrument of Indian corporate sector to tap international financial market. FCCB is actually a combination of two separate instrument, first one "Foreign currency bond" which means this bond is issued in foreign currency similar as Euro bond, Yankee bond etc.. Second one is "convertible bond" means this bond can be converted as the ordinary shares of the issuing company on agreed conversion. Indeed, the bull run in the Indian stock market have been a motivating factor to the Indian corporate sector to issue FCCB, according to prime database during 2005 to 2008 Indian corporate sector have witnessed good amount of inflow of foreign funds through FCCBs as around 201 Indian companies raised Rs. 72000 crore through FCCBs during that period. As per 
the report of Reserve bank of India (RBI) 320 approvals have been given to various companies under the automatic and approval route to issue FCCBs during $31^{\text {st }}$ October 2004 to $31^{\text {st }}$ October 2019. The key factors which encourage the Indian corporate to choose FCCBs for fund over other instrument is the low cost of capital and high conversion possibility during bull run. The amount raised through FCCBs may leads to positive signal to the market which may attract the potential shareholders to invest in the companies' shares and help the existing shareholders to increase their wealth. In contrast the fear of dilution in ownership due to conversion of FCCBs, coupon payments, exchange rate risk associated with FCCBs, and requirement of huge amount for redemption \& premium payment in the case of non-conversion etc. factors may leads to negative signal to the market which may result in panic within the existing shareholders and may discourage the potential shareholders. The share prices movement in the market due to the FCCB issue is depending upon the perception of shareholders on FCCBs issues.

From the Indian context if the effect on shareholder wealth due to the issue or issue announcement of FCCBs need to be analyzed then crisis period overlapping issue must be addressed because Out of 320 approval given by the Reserve bank of India(RBI) 267 FCCB issue approvals were given during 2004 to 2010 which include major crisis period of Indian stock market (2008-09), during this period there is a high chance that share price might have influenced by crisis, so we cannot draw a proper conclusion about wealth effects from FCCB issue until and unless overlapping possibility is not addressed. Therefore, in this study attempt to investigate the wealth effects from FCCBs issue by taking only pre-crisis period FCCB into the consideration. In short only the FCCB issue during the Bull Run (2004-2007) of the Indian stock market are considered.

\section{REVIEW OF LITERATURE}

The wealth effects associated with the issue and issue announcement of foreign currency convertible bonds (FCCBs) is untapped area however the wealth effect associated with foreign currency and convertible bond is widely studied. The studied shows both positive and negative wealth effects associated with the convertible bonds but as majority negative wealth effects are observed. Dann and Mikkelson (1984), Mikkelson and Partch (1986), Eckbo(1986), Kang et al. (1995), Abhyankar and Dunning(1999), Burlacu (2000), Arshanapalli et al. (2004), Cheng et al. (2005), Dutordoir and Van de Gucht, (2004), Fenech(2008) Wang et al. (2014) and Rahim (2012) are the few studies which who find the negative wealth effects due to the issue or issue announcement of the convertible bond whereas the Kang and Stulz (1996) and de Roon and Veld (1998) shows the positive wealth effect from the convertible bond issue and issue announcement . Even the study related to the foreign currency bond by Kim and Stutz (1988) and Darius and John (2001) shows the positive wealth effects. As discussed in the introduction part the FCCBs as combination of the two instrument will have either positive or negative impact on shareholders wealth but the general view point supports the positive effects from the FCCB issue and issue announcement during the bull run of the Indian stock market due to the high conversion possibilities, low cost of capital and as tool for the growth of business.

\section{OBJECTIVE OF THE STUDY}

The objective of the study is to examine the wealth effects associated with foreign currency convertible bonds (FCCBs) issued during the pre-crisis period by the Indian corporate sector.

The following Null Hypothesis is formulated

Ho: short-term abnormal stock returns of FCCB issuer company shareholders during precrisis period are not significantly different from zero or $\mathrm{CAAR}=0$. 
Fccbs Issue and Wealth Effects -A Pre-Crisis Period Perspective: Evidence from Indian Corporate Sector

\section{DATA AND METHODOLOGY}

As per RBI database and prowess IQ Database around 214 FCCB issue approvals were given during 2004 to 2007. But the approved and issued data differs. We have considered FCCB issue as a "event". The data related to FCCBs issue are obtained from Thomson Reuters Eikon Database. According to the database there was 258 FCCB issues in India since 2004. After the filters and eliminations as per the event study methodology requirement 151 FCCB issues which was issued during 2004 to 2007 are considered as sample. As a parameter for the market model the index closing of Sensex is considered for the same period and the relevant data is obtained from the Prowss IQ data base.

Our study employed the event study methodology (Brown and Warner, 1985). Event day $(\mathrm{t}=0)$ in our study is the day in which the FCCB is issued. We have used 41 day (from 20 days pre-issue to post 20 days of issue) as broad event window and few other sub event windows for the analysis of wealth effect on the basis of Abnormal returns (ARs), Average Abnormal Returns (AARs) and Cumulative Average Abnormal Returns (CAARs) and the significance tests of AARs and CAARs as per event study methodology. The estimation period of $200(-221$ to -21) days, i.e., 21 days before the issue date till 221 days before issue date, has been used to compute the parameters ( $\alpha$ and $\beta$ ) of the market model. The following figure shows the shows the timeline of event study used in this study

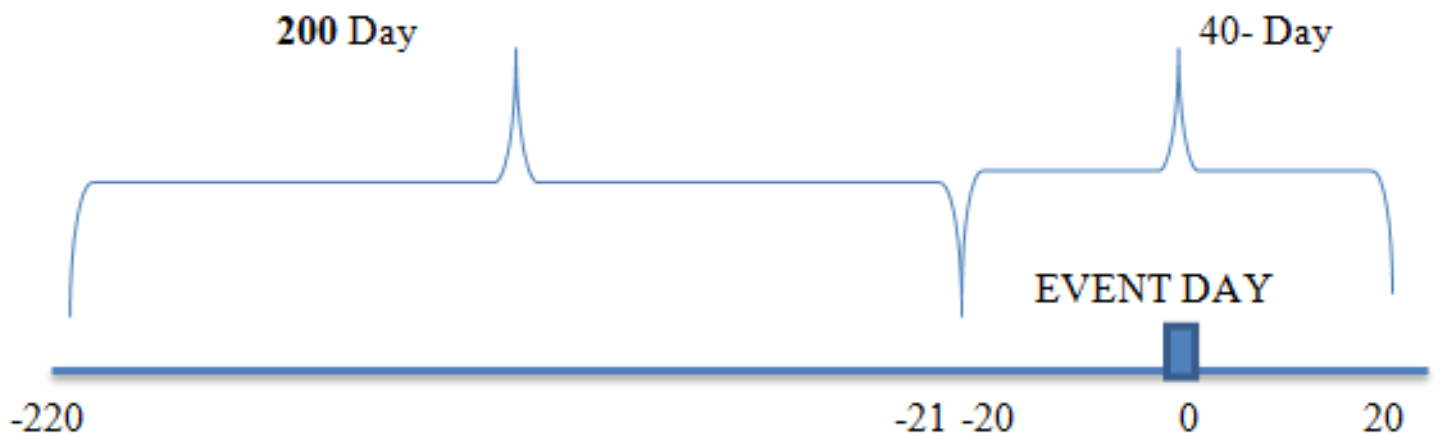

Estimation Window

Event Window

Figure 1 Timeline event

\section{RESULT AND DISCUSSION}

The results of analysis as per the event study methodology (Brown and Warner, 1985) which intended to investigate the wealth effects associated with the FCCBs issue during pre-crisis period by Indian corporate sector shows negative Average Abnormal Returns (AARs) of -0.26 on event day, however this is not statistically significant as the $t$ value is -1.0480 (at the 5 percent level of significance). The 151 FCCBs issued during 2004 to 2007 doesn't create notable impact on shareholders wealth on issue day but the negative AARs is not a good indicator. From the result we can understand that in India even in the Bull Run the FCCB issues failed to create a positive impact on shareholders wealth. The AARs and CAARs for the broad window of 41 day is presented in the table (1) which clearly shows the mixed AARs and CAARS i.e. both positive and negative percentage. The event day and post event means post issue up to 10 days ( 0 and +10 days) recoded negative AARs which also indicate about the negative signals in the market on FCCB issue. 
Table 1 AARs and CAARs for the broad window of 41 days

\begin{tabular}{|c|c|c|c|c|c|c|}
\hline Day & AARs & CAARs & Day & AARs & CAARs & \\
\hline $\mathbf{- 2 0}$ & $0.16 \%$ & $0.16 \%$ & 1 & $-0.31 \%$ & $0.79 \%$ & \\
\hline $\mathbf{- 1 9}$ & $-0.24 \%$ & $-0.08 \%$ & 2 & $-0.08 \%$ & $0.71 \%$ & \\
\hline $\mathbf{- 1 8}$ & $0.07 \%$ & $-0.01 \%$ & 3 & $0.00 \%$ & $0.71 \%$ & \\
\hline $\mathbf{- 1 7}$ & $0.31 \%$ & $0.30 \%$ & 4 & $0.03 \%$ & $0.75 \%$ & \\
\hline $\mathbf{- 1 6}$ & $0.07 \%$ & $0.38 \%$ & 5 & $-0.24 \%$ & $0.51 \%$ & \\
\hline $\mathbf{- 1 5}$ & $0.08 \%$ & $0.46 \%$ & 6 & $-0.25 \%$ & $0.26 \%$ & \\
\hline $\mathbf{- 1 4}$ & $-0.14 \%$ & $0.31 \%$ & 7 & $-0.09 \%$ & $0.17 \%$ & \\
\hline $\mathbf{- 1 3}$ & $0.26 \%$ & $0.57 \%$ & 8 & $-0.28 \%$ & $-0.11 \%$ & \\
\hline $\mathbf{- 1 2}$ & $0.21 \%$ & $0.78 \%$ & 9 & $-0.13 \%$ & $-0.24 \%$ & \\
\hline $\mathbf{- 1 1}$ & $0.08 \%$ & $0.86 \%$ & 10 & $0.10 \%$ & $-0.14 \%$ & \\
\hline $\mathbf{- 1 0}$ & $0.30 \%$ & $1.16 \%$ & 11 & $0.44 \%$ & $0.30 \%$ & \\
\hline $\mathbf{- 9}$ & $-0.11 \%$ & $1.05 \%$ & 12 & $0.29 \%$ & $0.58 \%$ & \\
\hline $\mathbf{- 8}$ & $0.09 \%$ & $1.14 \%$ & 13 & $0.12 \%$ & $0.71 \%$ & \\
\hline $\mathbf{- 7}$ & $0.07 \%$ & $1.21 \%$ & 14 & $-0.06 \%$ & $0.65 \%$ & \\
\hline $\mathbf{- 6}$ & $0.23 \%$ & $1.44 \%$ & 15 & $0.22 \%$ & $0.87 \%$ & \\
\hline $\mathbf{- 5}$ & $-0.16 \%$ & $1.28 \%$ & 16 & $-0.13 \%$ & $0.74 \%$ & \\
\hline $\mathbf{- 4}$ & $0.11 \%$ & $1.39 \%$ & 17 & $-0.28 \%$ & $0.46 \%$ & \\
\hline $\mathbf{- 3}$ & $-0.25 \%$ & $1.14 \%$ & 18 & $0.10 \%$ & $0.56 \%$ & \\
\hline $\mathbf{- 2}$ & $0.29 \%$ & $1.43 \%$ & 19 & $-0.11 \%$ & $0.46 \%$ & \\
\hline $\mathbf{- 1}$ & $-0.07 \%$ & $1.36 \%$ & 20 & $-0.27 \%$ & $0.19 \%$ & \\
\hline $\mathbf{0}$ & $-0.26 \%$ & $1.10 \%$ & & & & \\
\hline
\end{tabular}

AARs (\%) and CAARs (\%) over a 41 days event window

The movement of AARs and CAARs is presented in fig (2) and fig (3) which clearly indicate about the pre-issue and post issue reactions of shareholders on FCCBs issue.

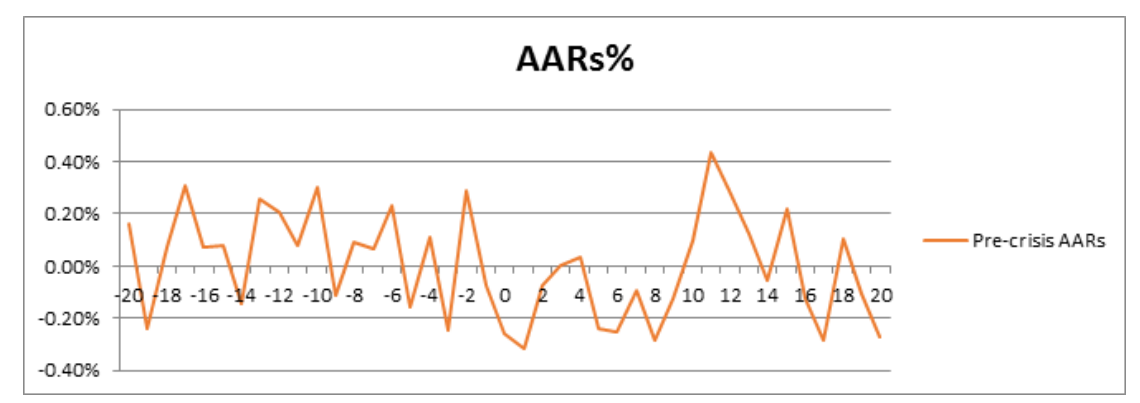

Figure 2 Pre-Issue reactions of Shareholders on FCCBs Issue

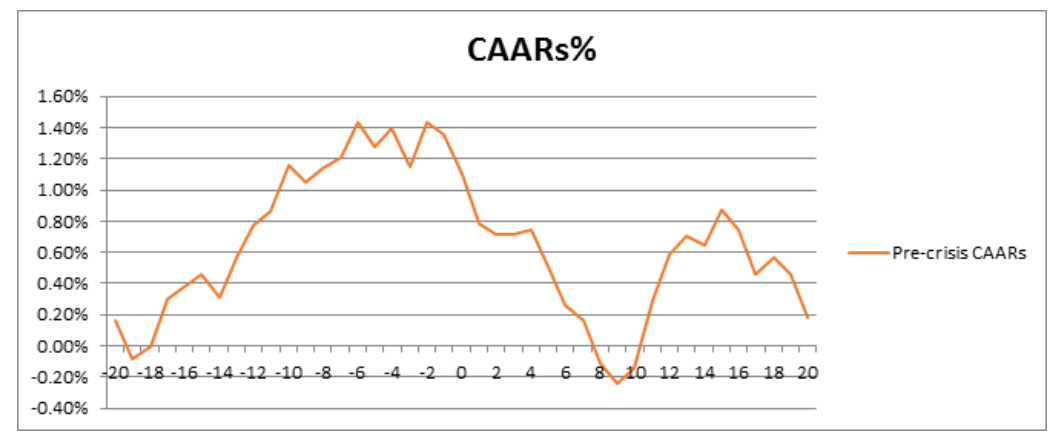

Figure 3 Post-Issue reactions of Shareholders on FCCBs Issue 
Fccbs Issue and Wealth Effects -A Pre-Crisis Period Perspective: Evidence from Indian Corporate Sector

As mentioned in the methodology section, we have used around 13 sub event windows in order to verify the wealth effects from the FCCB issue in a proper manner. The table (2) represents the respective CAARs along with the t-value under different event window. Out of 14 event windows 4 shows the positive CAARs but not statistically significant and rest 10 shows non-significant negative CAARs. The CAARs percentage of Post-event window of 3day $(+1,+3)$, Post-event window of 5-day $(+1,+5)$ and Post-event window of 10-day $(+1,+10)$ are negative which is well indicate about the negative impact of the FCCB issue as discussed above.

Table 2 CAARs along with the t-value

\begin{tabular}{|c|c|c|}
\hline \multirow{2}{*}{ Event windows } & \multicolumn{2}{|c|}{ Pre-crisis period (2004-2007) } \\
\cline { 2 - 3 } & CAARs (\%) & t-value \\
\hline 41-day $(-20,+20)$ & $0.19 \%$ & 0.119 \\
\hline 31-day $(-15,+15)$ & $0.49 \%$ & 0.359 \\
\hline 21-day $(-10,+10)$ & $-1.00 \%$ & -0.889 \\
\hline 11-day $(-5,+5)$ & $-0.93 \%$ & -1.135 \\
\hline 5-day $(-2,+2)$ & $-0.43 \%$ & -0.789 \\
\hline 3-day (-1,+1) & $-0.65 \%$ & -1.519 \\
\hline Pre-event window of 20-day $(-20,-1)$ & $1.36 \%$ & 1.235 \\
\hline Pre-event window of 10-day $(-10,-1)$ & $0.50 \%$ & 0.643 \\
\hline Pre-event window of 5-day $(-5,-1)$ & $-0.08 \%$ & -0.143 \\
\hline Pre-event window of 3-day $(-3,-1)$ & $-0.03 \%$ & -0.079 \\
\hline Post-event window of 20-day $(+1,+20)$ & $-0.91 \%$ & -0.831 \\
\hline Post-event window of 10-day $(+1,+10)$ & $-1.24 \%$ & -1.600 \\
\hline Post-event window of 5-day $(+1,+5)$ & $-0.59 \%$ & -1.073 \\
\hline Post-event window of 3-day $(+1,+3)$ & $-0.39 \%$ & -0.907 \\
\hline
\end{tabular}

CAARs $(\%)$ and $\mathrm{t}$-value over a different event window

The results of our study support the majority of studies on "convertible bond issue effects" as the majority of the study found negative impact of convertible bond issue which even evident from the literature review of our study. but from the foreign currency bond point of view our result contradict previous studies even the general perception which we have mentioned in the literature proved wrong according to the results of the study.

\section{CONCLUSION}

Indeed, FCCBs have been a one of the instruments which Indian corporate prefers to raise fund from the international market. This study attempted to investigate the wealth effects from the FCCB, in order to avoid the overlapping possibilities FCCB issued during pre-crisis period was considered. Study finds the non-significant negative abnormal return on the event day i.e. FCCB issue day. The result indicates the negative impact of the FCCB issue on shareholders wealth even post 10 days of issue the negative impact is observed. However, this negative impact is not significant and some of the pre and post event windows/days recorded positive AARs and CAARs. 


\section{REFERENCES}

[1] Abhyankar, A., \& Dunning, A. (1999). Wealth effects of convertible bond and convertible preference share issues: An empirical analysis of the UK market. Journal of Banking and Finance, 23(7), 1043-1065.

[2] Arshanapalli, B., Switzer, L. N., Fabozzi, F. J., \& Gosselin, G. (2004). New Evidence on the Market Impact of Convertible Bond Issues in the U.S. Ssrn, 2960, 1-45.

[3] B. Espen Eckbo. (1986). VALUATION EFFECTS OF CORPORATE DEBT OFFERINGS. Journal of Financial Economics, 15(February), 119-151. Retrieved from

[4] Burlacu, R. (2000). New evidence on the pecking order hypothesis: the case of French convertible bonds. Journal of Multinational Financial Management, 10, 439-459.

[5] Cheng, W., Visaltanachoti, N., \& Kesayan, P. (2005). A Stock Market Reaction Following Convertible Bond Issuance : Evidence from Japan. International Journal of Business, 10(4), $1-25$.

[6] Dann, L. Y., \& Mikkelson, W. H. (1984). Convertible debt issuance, capital structure change and financing-related information. Some new evidence. Journal of Financial Economics, 13(2), 157-186.

[7] De Roon, F., \& Veld, C. (1998). Announcement effects of convertible bond loans and warrant-bond loans: An empirical analysis for the Dutch market. Journal of Banking and Finance, 22(12), 1481-1506.

[8] Dutordoir, M., \& Van de Gucht, L. (2009). Why do Western European firms issue convertibles instead of debt or equity? European Financial Management, 15(3), 563-583.

[9] Fenech, J. P. (2008). The stock market reaction to Australian convertible debt issues: New evidence. Investment Management and Financial Innovations, 5(3), 90-100.

[10] Kang, J. K., Kim, Y. C., Park, K. J., \& Stuiz, R. M. (1995). An Analysis of the Wealth Effects of Japanese Offshore Dollar-Denominated Convertible and Warrant Bond Issues. Journal of Financial and Quantitative Analysis, 30(2), 257-270.

[11] Kang, J. K. (1996). How different is Japanese corporate finance? An investigation of the information content of new security issues. Review of Financial Studies, 9(1), 109-139.

[12] Kim, Y. C., \& Stulz, R. M. (1988). The Eurobond market and corporate financial policy. Journal of Financial Economics, 22(2), 189-205.

[13] Mikkelson, W. H., \& Partch, M. M. (1986). Valuation effects of security offerings and the issuance process. Journal of Financial Economics, 15(1-2), 31-60.

[14] Miller, D. P., \& Puthenpurackal, J. J. (2002). The costs, wealth effects, and determinants of international capital rising: Evidence from public Yankee bonds. Journal of Financial Intermediation, 11(4), 455-485.

[15] Rahim, N. A. (2012). A study on the market reaction to hybrid securities announcements, (July), 1-142.

[16] Wang, B., Miao, J., \& Wang, F. (2014). Research on the announcement effects of the convertible bonds in the a-share market of china, (April), 333-340. 